Research article

Open Access

\title{
Synthesis and Characterization of Compounds Related to Lisinopril
}

\author{
Ambati V. RaghaVA RedDY * ${ }^{1,2}$, Srinivas GaRAgA ${ }^{1}$, \\ Chandiran TAKSHINAMOORTHY ${ }^{1}$, Andra NAIDU ${ }^{2}$, Ramesh DANDALA ${ }^{3}$
}

${ }^{1}$ Chemical Research and Development Department, Aurobindo Pharma Ltd, Survey No:71\&72, Indrakaran Village, Sangareddy Mandal, Medak district, Telangana, 502329, India.

2 Department of Chemistry, Jawaharlal Nehru Technological University Hyderabad, Kukatpally, Hyderabad, Telangana State, 500085, India.

${ }^{3}$ Affliated supervisor, Jawaharlal Nehru Technological University Hyderabad, Kukatpally, Hyderabad, Telangana State, 500085, India.

* Corresponding author. E-mail: raghavareddyav@yahoo.com (A. V. Raghava Reddy)

Sci Pharm. 2016; 84: 269-278

doi:10.3797/scipharm.1507-08

Published: $\quad$ October $18^{\text {th }} 2015$

Accepted: October $18^{\text {th }} 2015$

Received: July $9^{\text {th }} 2015$

This article is available from: http://dx.doi.org/10.3797/scipharm.1507-08

(c) Raghava Reddy et al.; licensee Österreichische Pharmazeutische Gesellschaft, Austria.

This is an Open Access article distributed under the terms of the Creative Commons Attribution License (http://creativecommons.org/licenses/by/3.0/), which permits unrestricted use, distribution, and reproduction in any medium, provided the original work is properly cited.

\begin{abstract}
Lisinopril is a drug of the angiotensin-converting enzyme (ACE) inhibitor class that is primarily used in the treatment of hypertension. During the scale-up of the lisinopril process, one unknown impurity was observed and is identified. The present work describes the origin, synthesis, characterization, and control of this impurity. This paper also describes the synthesis and characterization of three other impurities listed in the European Pharmacopoeia 8.4 (Impurity C, D, and F).
\end{abstract}

\section{Keywords}

Lisinopril • Related substances $\bullet$ Origin $\bullet$ Synthesis $\bullet$ Characterization $\bullet$ Impurities

\section{Introduction}

Lisinopril is the third ACE inhibitor after captopril and enalapril, and is chemically known as $N^{2}$-[(1S)-1-Carboxy-3-phenylpropyl]-L-lysyl-L-proline. Lisinopril is marketed by Merck under the brand name of PRINVIL ${ }^{\circledR}$. 


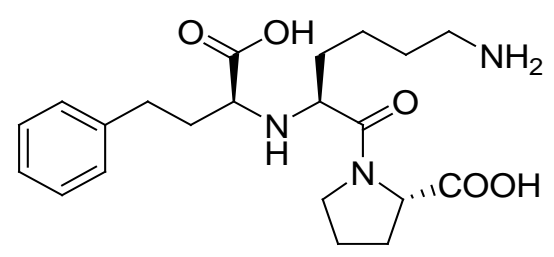

Fig. 1. Structure of lisinopril.

The presence of impurities in an Active Pharmaceutical Ingredient (API) will influence the quality and safety of the drug product. Hence, an impurity profile study has to be carried out for any drug substance and it is also a regulatory requirement to identify and characterize all unknown impurities. Further, impurities are required in pure form to check the analytical performance characteristics such as specificity, linearity, range, accuracy, precision, limit of detection (LOD), limit of quantification (LOQ), robustness, system suitability testing, and relative retention factor $[1,2]$.

During the scale-up of the lisinopril process, one unknown impurity was observed at a level of $0.1-0.2 \%$ long with other impurities listed in the European Pharmacopoeia [3]. The unknown impurity detected was monitored and its structure was tentatively assigned on the basis of its fragmentation patterns in the LC-MS analysis. Further, this impurity was synthesized, characterized, and co-injected with lisinopril in HPLC analysis to confirm its structure. Based on the structural data, the chemical name of this impurity is 2-(1-(5amino-1-carboxypentylcarbamoyl)-5-aminopentylamino)-4-phenylbutanoic acid ( $N^{2}-(1$ Carboxy-3-phenylpropyl)lysyllysine, lysine analogue). The present work also describes the synthesis and characterization of three other known impurities by various spectroscopic techniques.

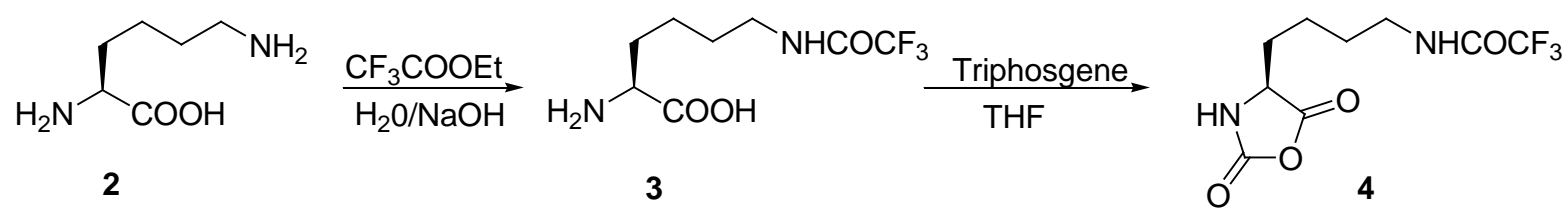

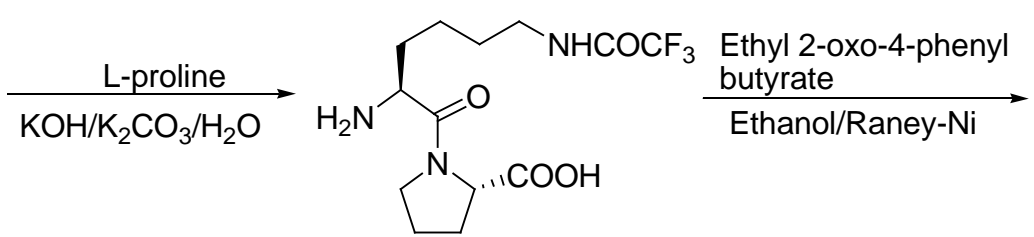

5<smiles>CCOC(=O)[C@H](CCCCNC(=O)C(F)F)N[C@@H](CCCNC(=O)O)C(=O)N1CCC[C@H]1C(=O)O</smiles>

6<smiles>C[C@H](N[C@@H](CCCCN)C(=O)O)C(=O)N1CCC[C@H]1C(=O)O</smiles>

Sch. 1. Reported synthetic route for lisinopril. 


\section{Results and Discussion}

Lisinopril 1 has been synthesized by known literature methods [4,5]. Our route of synthesis for lisinopril is shown in Scheme 1. L-lysine (2) was reacted with ethyltrifluoro acetate to obtain $N^{6}$-trifluoroacetyl-L-lysine (3). Compound $\mathbf{3}$ was treated with triphosgene to obtain $N^{6}$-trifluoroacetyl- $N^{2}$-carboxy-L-lysine anhydride (4), which was condensed with $L$-proline to get $N^{6}$-trifluoroacetyl-L-lysyl-L-proline (5). Compound 5 was condensed with ethyl 2-oxo4-phenyl butyrate followed by hydrogenation in the presence of the Raney-Nickel catalyst to get $N^{2}-\left(1-(S)\right.$-ethoxycarbonyl-3-phenylpropyl)- $L-N^{6}$-(trifluoroacetyl)- $L$-lysyl- $L$-proline (6). Finally, compound $\mathbf{6}$ was hydrolyzed with sodium hydroxide which resulted in lisinopril 1.

This paper reports the synthesis and characterization of the unknown impurity (lysine analogue) along with three known impurities [6-18].<smiles>NCCCCC(NC(CCCCN)C(=O)NC(CCc1ccccc1)C(=O)O)C(=O)O</smiles>

Fig. 2. Chemical structure of the lysine analogue 7.

The chemical structures of the impurities listed in the European Pharmacopoeia 8.4 are given below: $(S, S, S)$-diketopiperazine (8), (R,S,S)-diketopiperazine (9), and cyclohexyl analogue (10).<smiles>NCCCC[C@H]1C(=O)N2CCC[C@H]2C(=O)N1C(CCc1ccccc1)C(=O)O</smiles>

8<smiles>NCCCC[C@H]1C(=O)N2CCC[C@H]2C(=O)N1[C@H](CCc1ccccc1)C(=O)O</smiles>

9<smiles>NCCCCC(NC(CCC1CCCCC1)C(=O)O)C(=O)N1CCCC1C(=O)O</smiles>

Fig. 3. Structures of lisinopril impurities.

The chemical names of the impurities 7-10 are given below.

$N^{2}$-(1-Carboxy-3-phenylpropyl)lysyllysine (7, lysine analogue).

(2S)-2-[(3S,8aS)-3-(4-Aminobutyl)-1,4-dioxohexahydropyrrolo[1,2-a]pyrazin-2(1H)yl]-4-phenylbutanoic acid [8, (S,S,S)-Diketopiperazine, Ph. Eur Impurity-C)].

(2S)-2-[(3S,8aR)-3-(4-Aminobutyl)-1,4-dioxohexahydropyrrolo[1,2-a]pyrazin-2(1H)yl]-4-phenylbutanoic acid [9, $(R, S, S)$-Diketopiperazine, Ph. Eur Impurity-D)].

1-\{N²-[(1S)-1-Carboxy-3-cyclohexylpropyl]-L-lysyl\}-1H-pyrrole-2-carboxylic acid [10, (Cyclohexyl Analogue, Ph. Eur Impurity-F)]. 
The origin, synthesis, characterization, and control of these related substances are discussed individually. Each of the synthesized impurities was characterized by conventional spectroscopic studies and the presences of these impurities were confirmed by co-injection with the lisinopril sample. To the best of our knowledge, the synthesis of these related substances were not yet reported.

\section{Route Cause for the Formation of Lisinopril Lysine Analogue (7)}

Lysine analogue 7 formed due to the presence of unreacted protected lysine 3 in $N^{6}$-trifluoroacetyl- $N^{2}$-carboxy-L-lysine anhydride (4). This unreacted compound 3 underwent all the reactions employed for the synthesis of lisinopril to give lysine analogue 7.

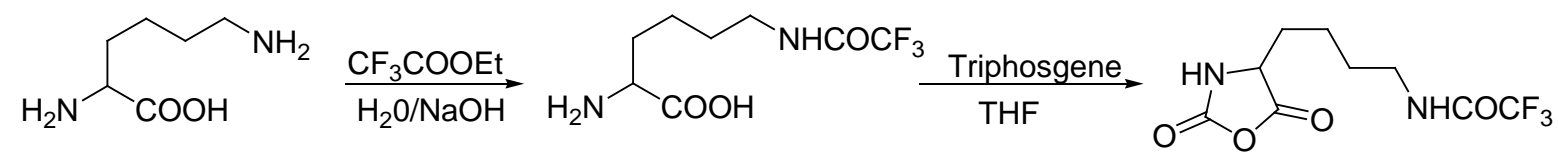
2

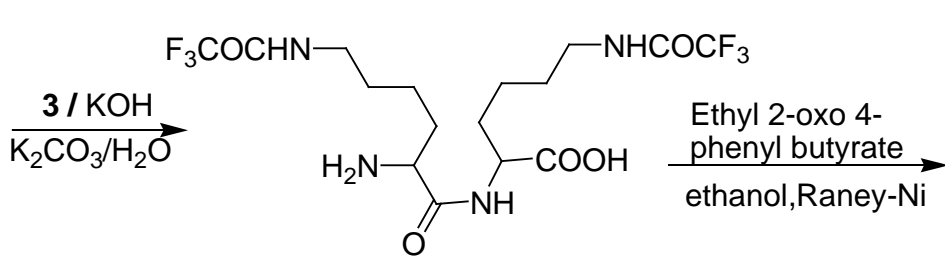

11<smiles>O=C(NCCCCC(NC(CCCCNC(=O)C(F)(F)F)C(=O)NC(CCc1ccccc1)C(=O)O)C(=O)O)OC(F)(F)F</smiles>

12<smiles>NCCCCC(NC(=O)C(CCCCN)NC(=O)C(=O)O)C(=O)O</smiles>

Sch. 2. Synthesis of lysine analogue 7.

Lysine analogue $\mathbf{7}$ was independently prepared by the condensation of compound $\mathbf{3}$ with $\mathbf{4}$ in the presence of potassium hydroxide and potassium carbonate to give condensed product 11. Compound $\mathbf{1 1}$ was reacted with ethyl 2-oxo-4-phenyl butyrate to form a Schiff base, which upon catalytic hydrogenation in the presence of Raney-Nickel, produced compound 12. Finally, compound $\mathbf{1 2}$ was hydrolysed to give lisinopril lysine analogue (7). The mass spectrum showed a molecular ion at $\mathrm{m} / \mathrm{z} 437.3$ amu $\left[(\mathrm{M}+\mathrm{H})^{+}\right]$. The ${ }^{1} \mathrm{H}-\mathrm{NMR}$ spectrum of 7 showed the presence of two $-\mathrm{NH}_{2}$ and two $-\mathrm{NH}$ groups which confirmed the assigned structure. 


\section{Route Cause for the Formation of (S,S,S)-diketopiperazine (Ph. Eur Impurity-C, 8)}

$(S, S, S)$-Diketopiperazine is the one of the listed impurities in lisinopril. This impurity may be formed due to intramolecular dehydration of lisinopril at high temperature.

$(S, S, S)$-Diketopiperazine was independently prepared by heating the n-butanol solution of lisinopril in the presence of hydrochloric acid at $80^{\circ} \mathrm{C}$. The spectral data of this impurity matched the reported results [16].
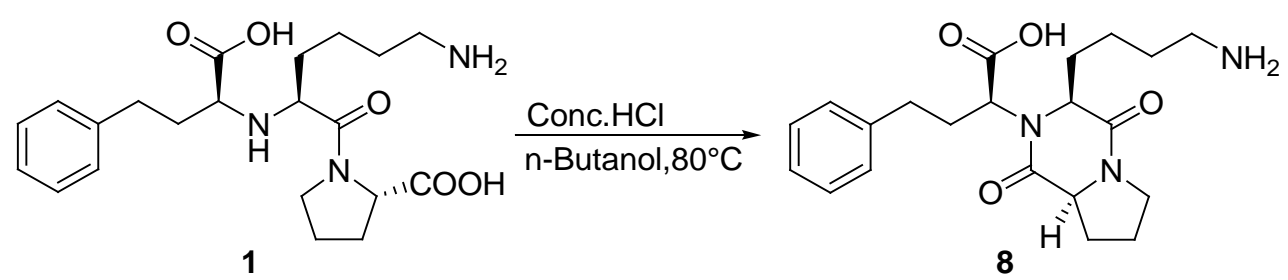

Sch. 3. Synthesis of $(S, S, S)$-diketopiperazine.

\section{Route Cause for the Formation of $(R, S, S)$-diketopiperazine (Ph. Eur Impurity-D, 9)}

$(\boldsymbol{R}, \boldsymbol{S}, \boldsymbol{S})$-Diketopiperazine is one of the known impurities in lisinopril. This impurity may be formed due to epimerization of Impurity- $C$ at high temperature.

$(\boldsymbol{R}, \mathbf{S}, \mathbf{S})$-Diketopiperazine was independently prepared by heating lisinopril at $190^{\circ} \mathrm{C}$. The spectral data of this impurity matched the reported results [16].
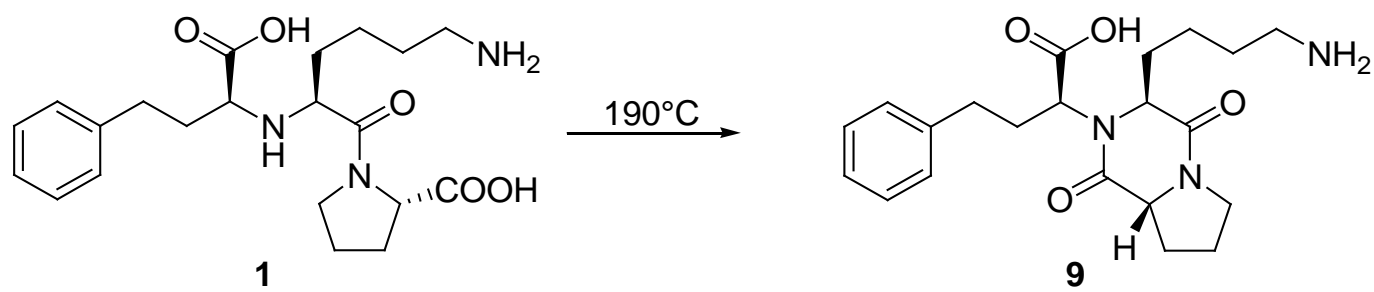

Sch. 4. Synthesis of $(R, S, S)$-diketopiperazine.

\section{Route Cause for the Formation of the Cyclohexyl Analogue (Ph. Eur Impurity-F)}

The cyclohexyl analogue is one of the known impurities in lisinopril. This impurity is formed due to the over-hydrogenation at the condensation reaction of compound $\mathbf{5}$ with ethyl 2-oxo-4-phenyl butyrate in the presence of Raney-Ni and $\mathrm{H}_{2}$ pressure. This impurity can be controlled by maintaining the controlled temperature and hydrogen pressure.

This cyclohexyl analogue was independently prepared by hydrogenation of lisinopril 1 with the Rodium catalyst in methanol. The mass spectrum showed a molecular ion at $\mathrm{m} / \mathrm{z} 411$ amu $\left[(\mathrm{M}+\mathrm{H})^{+}\right]$. The ${ }^{1} \mathrm{H}-\mathrm{NMR}$ spectrum of $\mathbf{1 0}$ showed the absence of aromatic protons, confirming the assigned structure. 
<smiles>NCCCC[C@H](NC(CCC1CCCC(C(=O)O)C1)C(=O)O)C(=O)N1CCC[C@H]1C(=O)O</smiles>

Sch. 5. Synthesis of the cyclohexyl analogue 10.

\section{Experimental}

Solvents and reagents were obtained from commercial sources and used without purification. ${ }^{1} \mathrm{H}-\mathrm{NMR}$ and ${ }^{13} \mathrm{C}-\mathrm{NMR}$ spectral data were performed on the Bruker-Avance 300-MHz Spectrometer in DMSO- $d_{6}$ and $\mathrm{D}_{2} \mathrm{O}$ wherever applicable. The chemical shift values were reported on the $\delta$ scale in parts per million $(p p m)$, downfield from tetramethylsilane (TMS) as an internal standard. The IR spectra were recorded in the solid state as KBr pellets using a Perkin-Elmer FT-IR Spectrophotometer. The mass spectrum was recorded using a Perkin-Elmer PE SCIEX-API 2000, equipped with an ESI source used online with an HPLC system after the ultraviolet (UV) detector.

\section{$N^{2}$-(1-Carboxy-3-phenylpropyl)lysyllysine (7, lysine analogue) [2-(1-(5-amino)-1-carboxypentylcarbamoyl)-5-aminopentylamino)-4-phenylbutanoic acid, 6-Amino-2-(\{6-amino-2-[(1-carboxy-3-phenylpropyl)amino]hexanoyl\}amino)- hexanoic acid]}

\section{Synthesis of compound 4}

To a solution of triphosgene $(25.8 \mathrm{~g}, 86.86 \mathrm{mmol})$ in tetrahydofuran $(250 \mathrm{~mL})$, compound 3 $(50 \mathrm{~g}, 206.6 \mathrm{mmol})$ was added at $25-30^{\circ} \mathrm{C}$. The reaction mixture was heated to $35-40^{\circ} \mathrm{C}$ and maintained for $20 \mathrm{~h}$. After completion of the reaction, we concentrated the reaction mass at $35-40^{\circ} \mathrm{C}$ under reduced pressure to obtain an oily mass 4 . (Note: this oily material was taken as such for the next step without characterization).

\section{Synthesis of compound 11}

To a mixture of potassium hydroxide $(30.62 \mathrm{~g}, 546.78 \mathrm{mmol})$, potassium carbonate (42.83 $\mathrm{g}, 310.36 \mathrm{mmol})$ in $\mathrm{DM}$ water $(700 \mathrm{~mL})$, and tetrahydrofuran $(500 \mathrm{~mL})$, was added protected lysine $3(50 \mathrm{~g}, 206.6 \mathrm{mmol})$ at $0-5^{\circ} \mathrm{C}$ followed by compound 4 . Thereafter, the reaction mass was stirred vigorously for 20 mins to complete the reaction. We adjusted the $\mathrm{pH}$ of the reaction mass to $\sim 5$ with sulfuric acid at $0-5^{\circ} \mathrm{C}$ and then concentrated it under reduced pressure at $35-40^{\circ} \mathrm{C}$ to obtain a residue. This residue was dissolved in methanol $(200 \mathrm{~mL})$ and we continued distillation to remove water completely. Again methanol (200 $\mathrm{mL})$ was added to the resulting syrupy mass and it was stirred for 20 mins at $25-30^{\circ} \mathrm{C}$. Inorganic salts thus precipitated were filtered and the filtrate was concentrated under reduced pressure at $35-40^{\circ} \mathrm{C}$. The resulting residue was titurated with MTBE to obtain 11 as a white solid (72 $\mathrm{g}, 75 \%)$.

${ }^{1} \mathrm{H}-\mathrm{NMR}$ (DMSO-D, $300 \mathrm{MHz}$ ): 1.29-1.41 (m, 12H), 4.02 (m, 2H), 8.57 (brs, NH), 9.50 (brs, NH) $p p m, m / z: 466.8\left[(\mathrm{M}+\mathrm{H})^{+}\right]$. 


\section{Synthesis of compound 7}

In one litre, a hydrogenator charged a solution of compound 11 (25 g, $53.64 \mathrm{mmol}$, in 400 $\mathrm{mL}$ methanol), and to it was added molecular sieves powder (50 g, type 3A) followed by ethyl-2-oxo-4-phenyl butyrate (13.81 g, $67 \mathrm{mmol})$ and Raney-Ni (25 g). Continued hydrogenation was done at $25-30^{\circ} \mathrm{C}$ with $4 \mathrm{~kg} / \mathrm{cm}^{2}$ hydrogen pressure for $16 \mathrm{~h}$. The reaction was monitored by TLC and after completion of the reaction, the mass was carefully filtered under nitrogen atmosphere to remove the Raney-Nickel catalyst. The methanol filtrate was concentrated and the residue obtained was dissolved in DM water $(125 \mathrm{~mL})$. We adjusted the $\mathrm{pH}$ to 8.0 with $5 \% \mathrm{w} / \mathrm{w}$ aqueous sodium bicarbonate solution and then washed it with toluene $(125 \mathrm{~mL})$. Dichloromethane $(125 \mathrm{~mL})$ was added to the aqueous layer and we adjusted the $\mathrm{pH}$ of the reaction mixture to 4.5 with concentrated hydrochloric acid. The organic layer was separated and concentrated under reduced pressure at $35-40^{\circ} \mathrm{C}$, resulting in compound 12 as a residue.

HPLC Purity: 96.54\%; ${ }^{1} \mathrm{H}-\mathrm{NMR}$ (DMSO-D, $\left.300 \mathrm{MHz}\right): 1.16(\mathrm{~m}, 3 \mathrm{H}), 1.16-1.19(\mathrm{~m}, 4 \mathrm{H})$, 1.21-1.28 (m, 6H), 1.42-1.49 (m, 4H), 2.50-2.51 (m, 2H), 2.92-3.35 (m, 6H), 4.07-4.10 (q, 2H), $4.11(\mathrm{~m}, 1 \mathrm{H}), 7.14-7.29(\mathrm{~m}, 5 \mathrm{H}), 7.90-7.93(\mathrm{~d}, 1 \mathrm{H}) \mathrm{ppm} ; \mathrm{MS} \mathrm{m} / \mathrm{z}$ : $657.1[(\mathrm{M}+\mathrm{H})+]$.

DM water (200 mL) was added to residue 12 and $\mathrm{pH}$ was adjusted to 12.5 with 50\% w/w aqueous sodium hydroxide solution. The reaction mass was stirred for $3 \mathrm{~h}$ at $40-45^{\circ} \mathrm{C}$ by maintaining $\mathrm{pH}$ at $12-12.5$ with $50 \% \mathrm{w} / \mathrm{w}$ aqueous sodium hydroxide solution. The reaction mass was cooled to $20-25^{\circ} \mathrm{C}$ and $\mathrm{pH}$ was adjusted to 5.0 with concentrated hydrochloric acid. The reaction mass was concentrated under reduced pressure at $35-40^{\circ} \mathrm{C}$. The residue was dissolved in methanol and concentrated at $35-40^{\circ} \mathrm{C}$ to ensure the complete removal of water. Again, methanol $(50 \mathrm{~mL})$ was added to the residue and stirred for 20 mins. The resulting inorganic salts were removed by filtration and the filtrate was concentrated under reduced pressure at $35-40^{\circ} \mathrm{C}$. The residue obtained was crystallized from acetone $(50 \mathrm{~mL})$ to obtain lysine analogue 7 (20 g, 83\%).

HPLC Purity: 96.16\%; IR ( $\mathrm{KBr}$ pellet, $\mathrm{cm}^{-1}$ ): 3434 (OH str), 3089 (Ar CH str) 2959-2870 (aliphatic $\mathrm{CH}$ str), 1640 ( $\mathrm{C}=\mathrm{O}$ str), $1454\left(\mathrm{CH}_{2}\right.$ bend); ${ }^{1} \mathrm{H}-\mathrm{NMR}\left(\mathrm{D}_{2} \mathrm{O}, 300 \mathrm{MHz}\right): 1.31-2.19$ $(\mathrm{m}, 14 \mathrm{H}), 2.76(\mathrm{~m}, 2 \mathrm{H}), 2.91-2.98(\mathrm{~m}, 4 \mathrm{H}), 3.36$ \& $3.98(2 \mathrm{~m}, 2 \mathrm{H}), 4.33(\mathrm{~m}, 1 \mathrm{H}), 7.28-7.37$ $(\mathrm{m}, 5 \mathrm{H}, \mathrm{Ar}) p p m ;{ }^{13} \mathrm{C}-\mathrm{NMR}\left(\mathrm{D}_{2} \mathrm{O}, 75 \mathrm{MHz}\right): 178.5,174.9,171.1,138.7,129.17,128.95$, 126.96, 61.1, 60.47, 53.78, 45.8, 45.3, 42.1, 32.9, 32.5, 32.1, 30.7, 28, 21, 21.1 ppm; MS $\mathrm{m} / \mathrm{z}: 437.3[(\mathrm{M}+\mathrm{H})+]$.

\section{(2S)-2-[(3S,8aS)-3-(4-Aminobutyl)-1,4-dioxohexahydropyrrolo[1,2-a]pyrazin-2(1H)-yl]- 4-phenylbutanoic acid [8, (S,S,S)-Diketopiperazine, Ph. Eur Impurity-C]}

To a suspension of lisinopril dihydrate $(50 \mathrm{~g}, 113.37 \mathrm{mmol})$ in $\mathrm{n}$-butanol $(500 \mathrm{~mL})$ was added concentrated hydrochloric acid $(12.9 \mathrm{~g})$ at $25-30^{\circ} \mathrm{C}$. The reaction mixture was heated to $75-80^{\circ} \mathrm{C}$ and stirred for $24 \mathrm{~h}$. The reaction was cooled to $25-30^{\circ} \mathrm{C}$ and $\mathrm{pH}$ was adjusted to 5.2 with $5 \mathrm{~N}$ sodium hydroxide. Thereafter, the reaction mixture was concentrated under reduced pressure to a syrupy mass. To the resulting syrupy mass was added $\mathrm{n}$-butanol $(100 \mathrm{~mL})$ and the salts were removed by filtration. The filtrate was concentrated under reduced pressure at $50-55^{\circ} \mathrm{C}$ resulting in an oily mass. The resulting oily mass was purified by column chromatography by using ethyl acetate and methanol to obtain (S, S,S)-diketopiperazine (20 g, 40\%). 
HPLC Purity: 90.48\%; IR ( $\mathrm{KBr}$ pellet, $\left.\mathrm{cm}^{-1}\right)$ : 3200-3600 (OH, NH str), 3000-2800 $\left(\mathrm{CH}_{2}\right)$, 1650 ( $\mathrm{C}=\mathrm{O}$ str), 1587 (asymmetric $\mathrm{CO}_{2}$ str), 1387 (symmetric $\mathrm{CO}_{2}$ str), 755,702 (aromatic $\mathrm{CH}$ out of plane); ${ }^{1} \mathrm{H}-\mathrm{NMR}\left(\mathrm{D}_{2} \mathrm{O}, 300 \mathrm{MHz}\right): 0.77-0.87(\mathrm{~m}, 1 \mathrm{H}), 1.44-2.07(\mathrm{~m}, 9 \mathrm{H})$, 2.33$2.84(\mathrm{~m}, 6 \mathrm{H}), 3.10-3.50(\mathrm{~m}, 3 \mathrm{H}), 3.76(\mathrm{dd}, 1 \mathrm{H}), 3.85$ (brs, 1H), 7.10-7.27 (m, 5H, Ar) ppm; MS $m / z: 387[(\mathrm{M}+\mathrm{H})+]$.

(2S)-2-[(3S,8aR)-3-(4-Aminobutyl)-1,4-dioxohexahydropyrrolo[1,2-a]pyrazin-2(1H)-yl]4-phenylbutanoic acid [9, (R,S,S)-Diketopiperazine, Ph. Eur Impurity-D)

Lisinopril dihydrate $(100 \mathrm{~g}, 226.7 \mathrm{mmol})$ was placed in an RB flask and heated to about $190^{\circ} \mathrm{C}$ with a continuous flow of nitrogen for $4 \mathrm{~h}$. The resulting molten residue was slowly cooled to $25-30^{\circ} \mathrm{C}$ and further purified through column chromatography by using ethyl acetate and a hexane mixture to obtain $50 \mathrm{~g}(58 \%)$ of compound 9.

HPLC Purity: 89.29\%; IR (KBr pellet, $\left.\mathrm{cm}^{-1}\right)$ : 3200-3600 (OH, NH str), 3000-2800 $\left(\mathrm{CH}_{2}\right)$, 1650 (C=O str), 1587 (asymmetric $\mathrm{CO}_{2}$ str), 1387 (symmetric $\mathrm{CO}_{2}$ str), 755, 702 (aromatic $\mathrm{CH}$ out of plane); ${ }^{1} \mathrm{H}-\mathrm{NMR}\left(\mathrm{D}_{2} \mathrm{O}, 300 \mathrm{MHz}\right): 1.17-1.22(\mathrm{~m}, 1 \mathrm{H}), 1.40-2.11(\mathrm{~m}, 9 \mathrm{H}), 2.33-$ $2.86(\mathrm{~m}, 6 \mathrm{H}), 3.66(\mathrm{t}, 1 \mathrm{H}), 3.80(\mathrm{dd}, 1 \mathrm{H}), 4.10(\mathrm{dd}, 1 \mathrm{H}), 7.10-7.23(\mathrm{~m}, 5 \mathrm{H}, \mathrm{Ar})$ ppm; MS $\mathrm{m} / \mathrm{z}: 387[(\mathrm{M}+\mathrm{H})+]$.

\section{1-\{N²-[(1S)-1-Carboxy-3-cyclohexylpropyl]-L-lysyl\}-1H-pyrrole-2-carboxylic acid 1-[(2S)-6-Amino-2-\{[(1S)-1-carboxy-3-cyclohexylpropyl]amino\}hexanoyl]-1H-pyrrole- 2-carboxylic acid (10, Cyclohexyl Analogue, Ph. Eur Impurity-F)}

To a solution of lisinopril dihydrate $(5 \mathrm{~g}, 11.33 \mathrm{mmol})$ in DM water $(5 \mathrm{~mL})$ and methanol (50 $\mathrm{mL})$ was added rhodium on carbon $(0.4 \mathrm{~g})$ at $25-30^{\circ} \mathrm{C}$. The reaction mixture was charged into the hydrogenator and $15 \mathrm{~kg} / \mathrm{cm}^{2}$ hydrogen pressure was applied at $25-30^{\circ} \mathrm{C}$. The reaction mass was stirred for $20 \mathrm{~h}$ at $25-30^{\circ} \mathrm{C}$ by maintaining hydrogen pressure at 15 $\mathrm{kg} / \mathrm{cm}^{2}$. Then reaction mixture was filtered and washed with methanol $(10 \mathrm{~mL})$ and concentrated under reduced pressure at $35-40^{\circ} \mathrm{C}$, resulting in a residue. The resulting residue was purified by column chromatography resulting in the desired product 10 (3.3 g, $60 \%)$.

HPLC Purity: 94.6\%; IR ( $\mathrm{KBr}$ pellet, $\left.\mathrm{cm}^{-1}\right)$ : 3200-3600 (OH, NH str), 2924-2851 $\left(\mathrm{CH}_{2}\right)$, 1644 (C=O str), 1449 ( $\mathrm{CH}_{2}$ bending), 1391 (symmetric $\mathrm{CO}_{2} \mathrm{str}$ ), 755, 702 (aromatic $\mathrm{CH}$ out of plane); ${ }^{1} \mathrm{H}-\mathrm{NMR}\left(\mathrm{D}_{2} \mathrm{O}, 300 \mathrm{MHz}\right): 0.78-2.10(\mathrm{~m}, 24 \mathrm{H}), 2.19-2.23(\mathrm{~m}, 1 \mathrm{H}), 2.95(\mathrm{t}, 2 \mathrm{H})$, $3.31(\mathrm{t}, 1 \mathrm{H}), 3.44-3.55(\mathrm{~m}, 2 \mathrm{H}), 3.76-4.28(\mathrm{~m}, 2 \mathrm{H}) \mathrm{ppm} ; \mathrm{MS} \mathrm{m} / \mathrm{z}: 411[(\mathrm{M}+\mathrm{H})+]$.

\section{Acknowledgement}

The authors gratefully acknowledge the management of Aurobindo Pharma Limited for allowing us to carry out this research work.

\section{Authors' Statement}

The authors declare no conflict of interest. 


\section{References}

[1] International Conference on Harmonization $(\mathrm{ICH})$ guidelines.

Q3A (R) impurities in New Drug Substances; ICH guidelines: Geneva, Switzerland, February 2002.

[2] International Conference on Harmonization (ICH) guidelines.

Q2B validation of analytical Procedure: Methodology, Geneva, Switzerland, November 6, 1996.

[3] European Pharmacopoeia 8.4, 4777-4778.

[4] Fischer J, Fodor T, Dobay L.

On the Michael type addition of dipeptides to 4-oxo-4-phenyl-2-butenoic acid derivatives.

Monatsh Chem. 1988; 119: 645-647.

http://dx.doi.org/10.1007/BF00809215

[5] Wu MT, Douglas AW, Ondeyka DL, Payne LG, Ikeler TJ, Joshua H, Patchett AA.

Synthesis of $\mathrm{N}^{2}$-[(S)-1-Carboxy-3-phenylpropyl]-L-lysyl-L-proline (lisinopril).

J Pharm Sci. 1985; 74: 352-354.

http://dx.doi.org/10.1002/jps.2600740330

[6] Zhu PX, Wang DH, Sun CR, Shen ZQ.

Characterization of impurities in the bulk drug lisinipril by liquid chromatography/ion trap spectroscopy. J Zhejiang Univ Sci B. 2008; 9: 385-390.

http://dx.doi.org/10.1631/jzus.B0820031

[7] Qin XZ, Nguyen DST, Ip DP.

Separation of lisinopril and its RSS diastereoisomer by micellar electrokinetic chromatography.

J Liqu Chromatogr. 1993; 16: 3713-3734.

http://dx.doi.org/10.1080/10826079308019663

[8] Stanisz B.

Kinetics of Lisinopril degradation in solid phase.

React Kinet Catal Lett. 2005; 85: 145-152.

http://dx.doi.org/10.1007/s11144-005-0254-x

[9] Whiteside RG, Games DE, Strawson C, Graham AS, Brown L.

Application of high speed CCC for the purification of lisinopril-diketopiperazine diastereomers.

J Liqu Chromatogr Rel Technol. 2001; 24: 1801-1810.

http://dx.doi.org/10.1081/JLC-100104380

[10] Hinojosa-Torres J, Aceves-Hernandez JM, Hinojosa-Torres J, Paz M, Castano VM, Agacino-Valdes E. Degradation of lisinopril: A physic-chemical study.

J Mol Struct. 2008; 886: 51-58.

http://dx.doi.org/10.1016/j.molstruc.2007.03.064

[11] Beasley CA, Shaw J, Zhao Z, Reed RA.

Development and validation of a stability indicating HPLC method for determination of lisinopril, lisinopril degradation product and parabens in the lisinopril extemporaneous formulation.

J Pharm Biomed Anal. 2005; 37: 559-567.

http://dx.doi.org/10.1016/j.jpba.2004.11.021

[12] Wang DH, Pei SF, Zhou MH, Sun CR, Pan YJ.

Characterization of novel impurity in bulk drug of lisinopril by multidimensional NMR technique.

J Zhejiang Univ Sci B. 2006; 7: 310-313.

http://dx.doi.org/10.1631/jzus.2006.B0310

[13] Sandor G.

Chemical and analytical characterization of related organic impurities in drugs.

Anal Bioanal Chem. 2003; 377: 852-862.

http://dx.doi.org/10.1007/s00216-003-2140-6 
[14] Ivanovic D, Medenica M, Jancic B, Knexevic N, Malenovic A, Milic J.

Validation of an analytical procedure for simultaneous determination of hydrochlorothiazide, lisinopril and their impurities.

Acta Chromatogr. 2007; 143-156.

http://dx.doi.org/10.1093/chromsci/bmu016

[15] Vikas S, Anurag T, Upadhayay PR, Gupta NL, Kanase DG, Chikate R.

Identification of a new impurity in lisinopril.

J Pharm Biomed Anal. 2007; 43: 381-386.

http://dx.doi.org/10.1016/j.jpba.2006.06.046

[16] Vijay K, Satish M, Saranjit S.

Polypill for the treatment of cardiovascular diseases part 2. LC-MS/TOF characterization of interation/degradation products of atenolol/lisinopril and aspirin, and mechanisms of formation thereof. J Pharm Biomed Anal. 2008; 48: 619-628.

http://dx.doi.org/10.1016/j.jpba.2008.06.003

[17] Shun-Li W, Shan-Yang L, Ting-Fang C.

Thermal-dependent dehydration process and intramolecular cyclization of Lisinopril dihydrate in the solid state.

Chem Pharn Bull. 2000; 48: 1890-1893.

http://dx.doi.org/10.1248/cpb.48.1890

[18] Cuirong S, Peixi Z, Nan H, Danhua W, Yuanjiang P.

Differentiation of lisinopril and its RSS diastereomer by liquid chromatography combined with collisioninduced dissociation mass spectrometry.

J Mass Spectrom. 2010; 45: 89-96.

http://dx.doi.org/10.1002/jms.1694 